\title{
A Translation Linguistic Setup-I AM in Spanish Language Context
}

\author{
Joel Laffita Rivera \\ Faculty of Applied Communication (FAC), Multimedia University, Cyberjaya, Malaysia \\ Email: Joel.laffita@mmu.edu.my
}

How to cite this paper: Rivera, J. L. (2020). A Translation Linguistic Setup-I AM in Spanish Language Context. Open Journal of Modern Linguistics, 10, 203-214. https://doi.org/10.4236/ojml.2020.104013

Received: January 14, 2020

Accepted: July 11, 2020

Published: July 14, 2020

Copyright $\odot 2020$ by author(s) and Scientific Research Publishing Inc. This work is licensed under the Creative Commons Attribution International License (CC BY 4.0).

http://creativecommons.org/licenses/by/4.0/

\begin{abstract}
The study aimed to provide selected syntax-functions of the phrase I AM in Spanish when using it in translation practices. It also deliveries teaching and learning insights that tap into the subject-matter-domain discussed. An oriented method based on collected and analyzed and added data was used to conduct the research study. The outcome showed that when translation is properly used in teaching and learning Spanish-syntax by taking as reference the translated phrase I AM in Spanish language context; this practice tents to foster cognitive skills and language competences among Spanish language learners up beginners level and benefit the learning process of the Spanish language grammar in this regard. It also revealed that the translation of this phrase can be used effectively in Spanish language contextual sentences and phrases. The present study is a gainful-approach for Spanish language bilingual Spanish/English teachers interested in applying translation-syntax-practices.
\end{abstract}

\section{Keywords}

Translation, Syntax, Linguistic, Foreign Language, Teaching, Learning

\section{Introduction}

The research study traces the use of translation as methodological vehicle to deliver various facets of linguistic functions of the phrase, I AM in Spanish language contextual sentences and phrases with emphasis on the use of the verbs to be (ser/estar), the verb to have (tener), nouns, and adjectives in Spanish language context. Applying grammar into Spanish contextual sentences and phrases continues to be a difficult task to digest and overcome by English native speakers and English second language speakers whose study Spanish language. This is a reality with which teachers have to deal when teaching Spanish grammatical functions to these learners (Colina \& Lafford, 2017). However, we can relate to 
translation practices in Spanish context to induce cognitive skills necessary for these learners to access moderate and complex grammar topics such as those above-described (August et al., 2002). For instance, by using as referent point the phrase, I AM in translated expressions such as "to be hungry"/"to be hot"/"to be told"/to be short/to be tired/to be content/to be a teacher/to be an engineer; learners will be able to observe and analyze Spanish linguistic traits such verbs-duality, verbs-convergence, nous and adjective gender-agreement. This will also enable them to associate, differentiate, and more importantly begin acknowledging the contrast between the Spanish verbs (ser/estar), the linguistic-convergence among them, the verb to have (tener) usage, and nouns and adjectives (gender-agreement) associated with this phrase in Spanish language contextual sentences and phrases. This translation practice makes visible that spectrum of linguistic functions that they need to acknowledge in order to use language as appropriate. The role of linguistic functions in second language acquisition must be focused (Bialystok, 1981). By using the translation of this phrase for teaching and learning Spanish language, those essential grammatical-linguistic-competences that are indispensable to determine in a considerable level such as, the correct writing and speaking when communicating these grammar subjects can be capitalized and inducted by these learners. This translation methodological prospect helps to understand the grammar used in sentences and phrases and their (words-order) too. The teaching and learning of these syntaxes can be effectively conducting by using the translated phrase of IAM in Spanish language context. Nonetheless, getting right its application in this language it will depend on how much we know about the syntax used and its linguistic functions in a given language. Therefore, taking this conceptual basis as the point of departure; the article outlines a sequence of research inputs based on this specific subject-knowledge-domain to implement the integration of translation in relation to the selected phrase in Spanish language context.

\section{Literature Review}

Translation has been a controversial element in the teaching of foreign languages (Cordero, 1984). The use of this discipline as a teaching language technique continues been viewed with suspicion by language teachers. Most probably the roots of this distrust begun with the misconception we had about the grammar translation method. According to some scholars the method does not fit well from the perspective of Applied Linguistics due to the overlooking of the speaking and listening skills (Kho, 2016). However, by withdrawing this method from our language classes we somehow dismissed the real value of it "translating grammar-components", which in terms of transferring linguistic skills and teaching syntax could benefit in many ways the learning process of a foreign language. The development of strategies for learning foreign language involves a set of operations and plans that assist in obtaining, storing, retrieving, and using important information. Furthermore, foreign language learners are motivated to un- 
derstand and learn new information through their intentional behavior and thoughts (Center for Research on Learning, 2011). Considering the remark "intentional behavior and thoughts", we could say that using the translation equivalence of lexical and grammatical between languages to emphasis on the level of complexities, contrast, and uniqueness of a given language would be in accordance to second language learners learning style (Datta, 2015). However, even though using translation is beneficial to gain L2 grammatical insights; it is necessary to put emphasis on the own-linguistic-characteristic that the L1 does, cited by (Rivera, 2019). The value of using translation in language practices have been drawn by many other research studies (Jing, 2015) defines translation as the process of conveying culture. (Duff, 1990); (Deller \& Rinvolucri, 2002); (Murphy, 1988); (Lonsdale, 1996) have addressed the significant of using translation in language class teaching and learning. Professionally speaking, applying translation techniques help in making students conscious of the degree to which languages coincide and differ. The applied-translation of the phrase, I AM in Spanish contextual sentence and phrases can help in mitigating unwanted learning results originated from the complexities of the linguistic-traits that Spanish language does have. So, applying grammar-themes when writing and speaking in Spanish correctly, it must-concern the teachers of this discipline. It is proved that using the translated phrase I AM when teaching and learning Spanish complex grammar themes such as the verbs (ser/estar/tener) and nouns and adjectives gender-agreement does work. Linguistically speaking, what we do need the most is to be well-equipped from the perspective of Applied Linguistics.

\section{Linguistic Translation Insights}

There are three specific syntax Spanish language characteristics to be considered when applying the phrase, I AM in Spanish contextual sentences and phrases. They are vital to strengthen and benefit the translation practice of it. Based on this regard, the three of them have been underlined, and a disclosure of their linguistic-applications put forward:

- The use of the personal subject pronouns (Yo/I) is not required.

- The verb "to be" has two verb-forms (ser and estar), and the differentiated-usage with which they are treated.

- The use of the verb to have (tener).

\section{Subject Pronoun Yo/I in Context}

Unlike English, in Spanish the subject pronoun (Yo/I) is not required in written or spoken sentences and phrases. So, in order to deal with this Spanish grammar specific trait; the conjugated form of the verb that follow it must be properly applied. See Table 1: Spanish tense and verb-forms.

\section{Accessing the Verb to Be and To Have Applications}

Knowing the functions of the verbs to be and to have is indispensable when it 
Table 1. Spanish tense and verb-forms.

\begin{tabular}{ccccc}
\hline Tense & Subject & $\begin{array}{c}\text { Verb-form to } \\
\text { be (ser) }\end{array}$ & $\begin{array}{c}\text { Verb-form to } \\
\text { be (estar) }\end{array}$ & $\begin{array}{c}\text { Verb-form to } \\
\text { have (tener) }\end{array}$ \\
\hline Present indicative & yo & soy & estoy & tengo \\
\hline
\end{tabular}

comes to translate the phrase I AM to Spanish sentences and phrases that require their use in this language. The contrast between the verb to be (ser) and to be (estar), the existence of linguistic-convergence between these two verbs, and the verb to have (tener) are of the most Spanish grammar traits to be focused when translating I AM to Spanish contextual sentences and phrases. See their linguistic applications below:

Verb to be (ser) usage inputs

Nationality (Yo soy español./Yo soy española.) I am Spanish.

Origin (Yo de España.) I am from Spain.

Ownership (Yo soy el dueño./Yo soy la dueña.) I am the owner.

Personality (Yo soy honesto./Yo soy honesta.) I am honest.

Physical characteristics (high, weight, race) (Yo soy alto, delgado y blanco. Yo soy alta, delgada y blanca.) I am told, thing and white.

Profession (Yo soy profesor. Yo soy profesora.) I am a teacher.

Occupation (Yo soy estudiante.) I am a student.

Recipient (Yo soy graduado de lingüística.) I am a graduated of linguistics.

Relationships (Yo soy el esposo de Ana. Yo soy la esposa de Luis.) I am the Ana's husband. I am the Luis's wife.

Religion (Yo soy cristiano. Yo soy cristiana.) I am a Christian.

Verb to be (estar) usage inputs

Feelings (Yo estoy enamorado. Yo estoy enamorad.) I am in love.

Emotions (Yo estoy feliz.) I am happy.

Concern (Yo estoy preocupado. Yo estoy preocupada.) I am worried.

Agreement (Yo estoy de acuardo.) I do agree.

Temporary physical stages (Yo estoy guapísimo. Yo estoy guapísima.) I am looking great.

Locations (Yo estoy en casa.) I am at home.

Temporary Physical condition (Yo estoy enfermo. Yo estoy enferma.) I am sick.

Marital status (Yo estoy casado. Yo estoy casada.) I am married.

Actions in progress (gerund) (Yo estoy comiendo./Yo estoy estudiando./Yo estoy trabajando./Yo estoy leyendo./Yo estoy durmiendo.) I am eating./I am studying./I am working./I am reading./I am sleeping.

\section{Verb to have (tener) usage inputs}

Physical characteristics (hair, eyes, skin) (Yo tengo el pelo negro. Yo tengo los ojos negros. Yo tengo la piel blanca.) I have black hair. I have black eyes. I have white skin. 
Possessions (Yo tengo casa. Yo tengo auto.) I have a house. I have a car. Age (Yo tengo 21 years old.) I am 21 years old.

Temporary physical needs (Yo tengo calor. Yo tengo frío. Yo tengo hambre.) I am hot. I am coul. I am hungry.

Obligation (to have to...) (Yo tengo que estudiar. Yo tengo que hacer la tarea./Yo tengo que ir a la universidad. Yo tengo que aprender español.) I have to study. I have to do the homework. I have to go to the university. I have to learn Spanish.

\section{Sentence/Phrase and Syntax Complements}

The phrase I AM could be classified as a subject-sentence (subject + verb). However, this phrase does not denote a clear meaning of what we might intend to write or say if we use it with no other added linguistic supplements, of course, excluding its use in an emphatically reply. So, the use nouns and adjectives for instance will play a vital role in defining and structuring the view of the speaker in writing and speaking: (I am a teacher. Yo soy profesor. Yo soy profesora.)/(I am exhausted. Yo estoy cansado. Yo estoy cansada.)/(I am cold. Yo tengo frío.)/(I am told and thing. Yo soy alto y delgado. Yo soy alta y delgada.). These sentences examples clearly exposed the differentiation and contrast of the syntax complements used in each language. While the phrase I AM remains unchanged in English, its translation to Spanish contextual sentences and phrases that requires the use of the verbs to be (ser/estar), to have (tener), nouns, and adjectives will suffer linguistic-modifications due to the 1 verb-duality, 2 verbcontrast; 3 verb-convergence; 4 nouns and adjective-usage. This is why insights about the first four statements have been provided in prior-segments of this research study and in the above-sentences and phrases examples. The use of (gender-agreement) between nouns and adjectives in Spanish contextual sentences and phrases where the verbs (ser and estar) are required is still one of the most difficult linguistic-point to digest and overcome. Therefore, it would be an advantage to know how nouns of professions and adjectives, including adjectives of nationalities are applied in Spanish language for learners to better comprehend this significant Spanish language grammar topic:

\section{Basic Rules}

- Nouns of professions/occupations that end in vowel "o" are usually masculine. To get the feminine form so that they agree with noun they describe, the vowel "o" is replaced for the vowel "a". The same rule applies to adjectives: Yo soy ingeniero. (a male speaker) Yo soy ingeniera. (a female speaker.). Yo estoy contento. (a male speaker) Yo estoy contenta. (a female speaker.)

- Nouns of professions/occupations that end in consonants are masculine. To get the feminine form so that they agree with noun they describe, the vowel "a" is added after the consonant. The same rule applies to adjectives: Yo soy doctor. (a male speaker) Yo soy doctora. (a female speaker.). Yo soy habal- 
dor. (a male speaker) Yo soy habladora. (a female speaker.)

- Nouns of professions/occupations that end in the suffix "ista" and vowel "e" are neuters. These kinds of nouns do not have gender, and the same rule applies to adjectives ending that way too: Yo soy dentista. Yo soy estudiante. (a male speaker) Yo soy dentista. Yo soy estudiante. (a female speaker.). Yo soy optimista. (a male speaker) Yo soy optimista. (a female speaker.) Adjectives of nationalities that end in "o" are masculine. Replace this vowel for "a" to get the feminine form. Those ending in "consonants" are masculine. Add "a" to get the female form (Yo soy mexicano-a./Yo soy spañol-a.). And those ending in "e" " $\mathrm{i}$ " "a" are neuters; they do not have gender (Yo soy canadiense. Yo soy iraní. Yo soy belga.)

\section{Teaching and Learning Strategies}

Employing translation as methodological prospect could helps Spanish language learners to empower the acquisition of grammar when integrated into classroom setting. Using it on Spanish grammar lessons plays an important role in teaching. It helps students to understand and explore the syntax-applications between languages. Thus, Spanish language teachers must consider providing translation teaching techniques through which Spanish language learners get a good understanding about the grammar-subjects to be taught. Based on this reality, this research study is setting up the following methodological insights to treat the Spanish language syntax exposed in this research-study by using the translated phrase I AM as referent point.

\subsection{A: Pragmatic Seput}

To start delivering this subject-matter-domain: teachers use Figure 1: I AM Translation Syntax Comparison to allow learners to compare the Spanish equivalent of the phrase I AM solo. Then, ask learners to use Goggle Translate as Tech-Tool to find out whether they fill up Table 2: Translation Syntax-Components Comparison with the translated Spanish sentences.

Table 2. Translation syntax-components comparison.

\begin{tabular}{l}
\hline IM-English Sentences \\
I am a student. \\
I am content. \\
I am in the classroom. \\
I am humgry. \\
I am thirsty. \\
I am 20 years old.
\end{tabular}




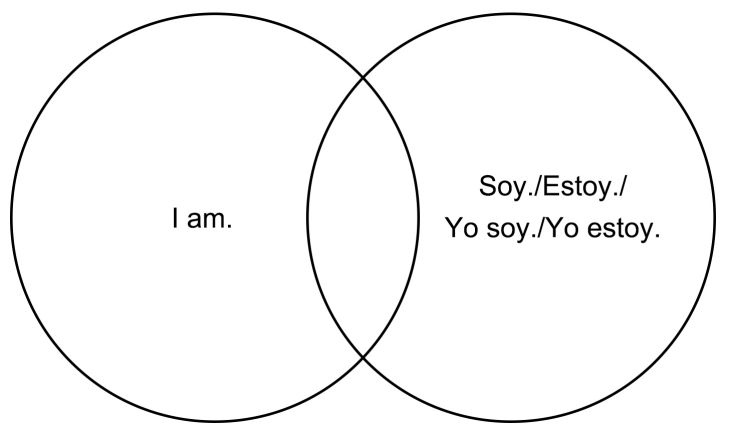

Figure 1. I AM translation syntax comparison.

\subsection{B: Pragmatic Seput}

To reinforce and crate awareness and discussion on the significance of using syntax components as appropriate in a given language; teachers ask learners to translate Spanish sentences and phrases to English that require the use of the verbs to be (ser/estar) accompanied by nouns of professions and descriptive adjectives. Then, ask learners to explain the use of syntax (verbs/nouns/adjectives) in Spanish.

\section{Examples}

Yo soy estudiante./Yo soy profesora./Yo estoy cansado. Yo estoy cansada./Yo soy alto y delgado. Yo soy alta y delgada./Yo soy guapo, honesto, responsable y optimista./Yo soy guapa, honesta, responsable y optimista.

\subsection{C: Pragmatic Seput}

To continue reinforcing and crating awareness and discussion on this significant subject-matter-domain; teachers ask learners to answers in Spanish a set of questions which they can translate themselves using Goggle Translate or any other Tech-tool for this purpose.

\section{Examples}

¿Eres Alberto?/¿Tú eres Alberto?

Sí soy.../No, no soy...

¿Estás cansado-a?

Sí estoy.../No, no estoy...

¿Tienes calor?/¿Tú tienes calor?

Sí tengo.../No, no tengo...

¿Cómo eres?

Soy alto y delgado./Yo soy alta y delgada

¿Cuántos años tienes?

Tengo.../Yo tengo...

By doing this based translation pragmatic-exercises, Spanish language learners up beginners' level will begin associating, differentiating and more important comprehending the significant of knowing the application of these complex-syntaxes in Spanish language contextual sentences and phrases. This translation approach 
will mark the beginning of a collaborative-working-environment, for which we will equip our Spanish language learners with appropriate learning-materials through which they will study the verb to be (ser/estar-usage); the verb to have (tener-usage); the use of nouns of professions/occupations and adjectives (gender-agreement) in Spanish language. This learning material can be extracted from the Linguistic-Translation-Insights Heading provided in this research-study. As a Spanish language teacher I do believe that it is essential to create a collaborative-working-class-environment to obtain good-linguistic-outputs when it comes to teach and learn the Spanish-grammar themes exposed in this manuscript and many others as well. I do believe also that using technology (Goggle Translator) is adapting students' learning preferences, and helping them to build their Spanish-language-development is equipping them with appropriate learning contents, materials and appropriate lecturer-assistance. Thus, the above-translationlanguage-practice is set to create that kind of engaging-learning-process through which, both, teacher and student can accomplish the linguistic-goal wanted in this respect.

\section{Study Methodology}

A based reviewing on various accredited documents such as books; Publications; Internet Webpages; Methods and classroom-observations were performed with the goal of strengthening and validating the general framework of this research-study. Stated facts and concerns have been exposed with the purpose of offering linguistic and methodological solutions to respond questions raised by Spanish novices' learners and teachers of this discipline.

\section{Research Questions}

- What is the difference between ser and estar?

- When and how using ser and estar?

- Why using to have instated of to be?

- What do I need to know the most to study these Spanish grammar themes?

- Can we as Spanish language teachers respond in a convinced way to these questions?

\section{Research Techniques Prospect}

Utilizing principles of research-techniques based on an oriented method of collecting and analyzing and adding data; the study began with the search of the Spanish language teaching and learning materials at the disposal for conducting this discipline when working with Spanish language learners up beginners' level. Spanish language books such as Basic Spanish (Ana, Jarvis, \& Francisco, 2014) and ¡En español! (Gahala, Carlin, Heining-Boynton, Otheguy, \& Rupert, 2000) were revised to find out what is detailed in their content in relation to the subject-matter-domain discussed in this research-study, basically by using translation teaching and learning approaches to access the Spanish grammar themes 
presented in this research study. Using the same search strategy several publications were analyzed and Internet Webpages searched in order to evaluate and demonstrate scientifically, veracities between the linguistics-insights provided in this research study and prior conducted researchers in Language Teaching and Learning field. A comparable-methodology-study of the Marco Común Europeo de Referencia para las Lenguas: aprendizaje, enseñanza, evaluación (Consejo de Europa, 2001) and the Spanish language curriculum of the Faculty of Applied Communication (FAC), Multimedia University was conducted to determine Spanish language teaching compatibilities and learning outcomes and domains. In supporting this effort, a number of classroom observations were carried out in Spanish language classes.

\section{Research Limitation Background}

The search was limited to analyze the use of translation in Spanish language practices. This assessment used inclusion criteria that are classified in Spanish Language curriculum-framework; 1) Learners' level novices; 2) Language proficiency-low beginners. 3) Teaching and Learning Spanish-syntax-methods. The time period to conduct the research was limited to one trimester of 43 credit hrs. for teaching Spanish. This research took place at Faculty of Applied Communication (FAC), Multimedia University (MMU), Malaysia.

\section{Results and Discussion}

The remarks stated in this research study are based on practical experiences gathered during teaching Spanish language learners up the beginner's level. The methodology strategies used in this research-study helped to present the facts of the elements accessible all over the content of the manuscript, which are based on the research purpose: 1) Research methodology. 2) Subject matter domain. 3) Results and discussion. 4). The study relates to the use translation-languagepractices to outline the degree of languages differentiation when translating the Spanish language syntaxes deliberated in this research-study by taking as reference point the phrase I AM. Issues regarding to Spanish-syntax-traits, Spanishsyntax-verbs-usage, sentences/phrases-usage and teaching/learning-insights have been presented in the literature-content of this research-study to highlight the benefits that can be derived from this conceptualization in translation language practices. The results have been presented in a logical sequence, given the most important research-rational-criteria first, and addressing the stated objective, which has been to provide valuable Spanish-syntax-linguistic-functions of the phrase I AM in translation practices and delivering teaching and learning insights that tap into the subject-matter-domain-discussed. Based on this aim the study discussed the grammatical-impact-issues related to the phrase I AM and other associated-linguistic-functions with it when translating it into Spanish language contextual sentences and phrases. Spanish-syntax-topics such the verb to be (ser/estar) and the verb to have (tener) and nouns-adjectives-gender-agre- 
ement which are correlated to the use of the phrase I AM in Spanish language have been capitalized in order to trace facts and respond questions from Spanish language teachers and the learners of this language subject. The teaching and learning of these complex-Spanish-syntaxes are still concerning Spanish language teachers and the learners of this language. Applying the verbs to be (ser) and (estar) and the verb to have (tener) in Spanish language contextual sentences and phrases continue to be a complicated-linguistic-issue for Spanish language novice learners to digest and overcome it. Therefore, the present research has attempted to respond questions regarding the accessibility of grammatical-functions. In this aspect, the research-article shows a reliable representation of collected and analyzed and added data related to the subject being deliberated. These text-references clearly stated the Spanish syntax to be considered when using the translated phrase, I AM and other associated linguistic supplements with it in Spanish language contextual sentences and phrases. The references also provide methodological insights to help Spanish language bilingual Spanish/English teachers setting approaches based on translation-grammarpractices.

\section{Recommendation}

Even though the use of translation continues to be subject of rejection in many Spanish language classroom setting; the fact of the matter is that teachers cannot stop students translating, mainly when working with language novice's learner. Using translation language practices in the early stage of a language learning process helps to induct language-traits which otherwise are complex to digest and overcome when learning grammar and grammatical functions in a given refers. Perhaps it could be controversial to say that the use of translation is relevance to the inductive-learning-process, which continues being applied as learning-method for acquiring Spanish grammar in Spanish language classes nowadays. Thus, further research-studies in the field of using translation to acquire Spanish grammar should be conducted in order to prepare novice learners to address a much more complex language learning situation created by issues such as verbs-duality; verbs-convergence; nous and adjective gender-agreement.

\section{Conclusion}

In conclusion, one could say that the manuscript presented contains significant literature sources corresponding to the main objective of the research article. The data presented in the manuscript contextualize clearly the subject-matterdomain exposed. In this regard, the study has presented a suitable literature material and methods with emphasis on Spanish syntax-translation-language-practices, based on which significant linguistic-results referring to the use of the phrase I AM solo and into contextual Spanish sentence and phrases have been drawn, matching that way the purpose of this research-study. The literature-content of this manuscript is a modest contribution to the field of applied linguistics. 


\section{Acknowledgements}

The author is very thankful to all the associated personnel in any reference that contributed in/for the purpose of this research.

\section{Webpages}

https://www.teachingenglish.org.uk/article/translation-activities-language-classr oom

https://grammar.spanishintexas.org/verbs/introduction-to-verbs/

https://www.spanishdict.com/translation

https://www.tandfonline.com/doi/full/10.1080/23247797.2017.1407127

https://www.jstor.org/stable/j.ctt1cn6sgb

\section{Monetary Funding}

The research has not been funded by any monetary source other than being sponsored by the professional interest of its author

\section{Conflicts of Interest}

The research holds no conflict of interest.

\section{References}

Ana, C., Jarvis, R. L., \& Francisco, M.-A. (2014). Basic Spanish.

August, D., Calderón, M., \& Carlo, M. (2002). The Transfer of Skills from Spanish to English: A Study of Young Learners. Washington DC: Center for Applied Linguistics.

Bialystok, E. (1981). The Role of Linguistic Knowledge in Second Language Use. Studies in Second Language Acquisition, 4, 31-45. https://doi.org/10.1017/S0272263100004265

Center for Research on Learning (2011). Learning Strategies. http://www.kucrl.org/sim/strategies.shtml

Colina, S., \& Lafford, B. A. (2017). Translation in Spanish Language Teaching: The Integration of a "Fifth Skill" in the Second Language Curriculum. Journal of Spanish Language Teaching, 4, 110-123. https://doi.org/10.1080/23247797.2017.1407127

Consejo de Europa (2001). Marco Común Europeo de Referencia para las Lenguas: Aprendizaje, enseñanza, evaluación. https://www.examenglish.com/CEFR/cefr_es.php

Cordero, A. D. (1984). The Role of Translation in Second Language Acquisition.

Datta, G. (2015). The Problems of Equivalence in Translation Toshniwal Arts. Sengaon: Commerce \& Science College.

Deller, S., \& Rinvolucri, M. (2002). Using the Mother Tongue: Making the Most of the Learner's Language. Delta Publishing.

Duff, A. (1990). Bringing Translation Back into the Language Class (Practical English Teaching 10/3).

Gahala, E., Carlin, P. H., Heining-Boynton, A. L., Otheguy, R., \& Rupert, B. J. (2000). McDougal Littell.

Jing, Y. (2015). The Application of Cultural Equivalence and Acceptability Principles in the Translation of East of the West. Nanjing: School of Foreign Languages and Culture, Nanjing Normal University. 
Kho, M.-J. (2016). How to Implant a Semiotic and Mathematical DNA into Learning English (261 p). Seoul: Booklab Publishing Co.

Lonsdale, A. (1996). Teaching Translation from Spanish to English: Worlds beyond Words. Ottawa: University of Ottawa Press. http://www.jstor.org/stable/j.ctt1cn6sgb https://doi.org/10.2307/j.ctt1cn6sgb

Murphy, B. (1988). Teaching Translation and Teaching through Translation (MET 15/4).

Rivera, J. (2019). Spanish Language Grammatical Context-Acknowledging Specific Language Characteristics. Open Journal of Modern Linguistics, 9, 215-228.

https://doi.org/10.4236/ojml.2019.93020 